\title{
Sifat Fisikokimia Minyak Buah Merah (Pandanus conoideus Lamk.) Degumming dan Karakteristik Mikroenkapsulat Minyak Buah Merah yang Dihasilkan
}

\author{
Physico-chemical Properties of Degumming Red Fruit Oil (Pandanus conoideus Lamk.) and \\ the Characteristics of the Red Fruit Microencapsulate
}

\author{
Indah Pratiwi ${ }^{1,2}$, Zita Letviany Sarungallo $^{1}$, Budi Santoso $^{{ }^{*}}$ \\ ${ }^{1}$ Program Studi lmu Pertanian, Fakultas Pasca Sarjana Universitas Papua (UNIPA), Jl. Gunung Salju Amban \\ Manokwari, Papua Barat. \\ ${ }^{2}$ Politeknik Pembangunan Pertanian (POLBANGTAN) Manokwari, Jl. Reremi SPMA Manokwari, Papua Barat. \\ *Email korespondensi: budsandida@yahoo.com
}

\begin{abstract}
Red fruit oil (Pandanus conoideus Lamk.) contains high levels of unsaturated fatty acids so that it is easily oxidized. Increasing the stability of carotenoids in red fruit oil can be done through microencapsulation technology. The research aimed to determine the physicochemical properties of red fruit oil and the characteristics of the red fruit oil microencapsulate. The research consisted of two stages, namely the degumming process of crude red fruit oil and the manufacture of red fruit oil microencapsules. The physicochemical properties of red fruit oil that were observed were viscosity, melting point, moisture content, free fatty acids, peroxide number, total ka-rotenoid, tocopherol, and iodine number. Observation of the characteristics of red fruit oil microencapsulate included moisture content, peroxide number, free fatty acids, fat content, total carotenoids, carotenoid retention, and solubility. The results showed the characteristics of degumming red fruit oil (DRFO), namely having a moisture content value of $0.78 \%, A L B 0.55 \%$, peroxide number $0.56 \mathrm{mg} \mathrm{O2} / \mathrm{g}$ of material, total carotenoids $5941 \mathrm{ppm}$, tocopherol $1586 \mathrm{ppm}$, iodine 66.53, melting point $21.5^{\circ} \mathrm{C}$ and viscosity 167 dPa.s. The characteristics of the DRFO microencapsulate were water content of $0.55 \%$, peroxide number $0.49 \mathrm{mg} \mathrm{O2} / \mathrm{g}$ of material, the fat content of $38.31 \%$, carotenoids $635 \mathrm{ppm}$, carotenoid retention of $97.17 \%$, and solubility of $93.45 \%$. The DRFO microencapsulate has met the standard of dry product quality according to Standard Nasional Indonesia for moisture content and peroxide number.
\end{abstract}

Keywords: red fruit oil (P. conoideus Lamk.), degumming, microencapsulate, physicochemical

\begin{abstract}
Abstrak
Minyak buah merah (Pandanus conoideus Lamk.) mengandung asam lemak tidak jenuh yang cukup tinggi sehingga sangat mudah teroksidasi. Peningkatan stabilitas karotenoid dalam minyak buah merah dapat dilakukan melalui teknologi mikroenkapsulasi. Penelitian bertujuan untuk menentukan sifat fisikokimia minyak buah merah dan mikroenkapsulat minyak buah merah. Penelitian terdiri dari dua tahap, yaitu proses degumming minyak buah merah kasar dan pembuatan mikroenkapsulat minyak buah merah. Sifat fisikokimia minyak buah merah yang diamati adalah viskositas, titik cair, kadar air, asam lemak bebas, bilangan peroksida, total karotenoid, tokoferol, bilangan iod. Pengamatan karakteristik mikroenkapsulat minyak buah merah meliputi kadar air, bilangan peroksida, asam lemak bebas, kadar lemak, total karotenoid, retensi karotenoid, dan kelarutan. Hasil penelitian menunjukkan karakteristik minyak buah merah degumming (MBMD) yaitu memiliki nilai kadar air 0,78\%, ALB 0,55\%, bilangan peroksida $0,56 \mathrm{mg} \mathrm{O} / \mathrm{gr}$ bahan, total karotenoid $5941 \mathrm{ppm}$, tokoferol $1586 \mathrm{ppm}$, bilangan iod 66,53 , titik cair $21,5^{\circ} \mathrm{C}$ dan viskositas $167 \mathrm{dPa}$.s. Karakteristik mikroenkapsulat MBMD yaitu memiliki kadar air $0,55 \%$, bilangan peroksida $0,49 \mathrm{mg} \mathrm{O}_{2} / \mathrm{gr}$ bahan, kadar lemak $38,31 \%$, karotenoid 635 ppm, retensi karotenoid 97,17\% dan kelarutan 93,45\%. Mikroenkapsulat MBMD memenuhi standar mutu produk kering menurut Standar Nasional Indonesia untuk kadar air dan bilangan peroksida.
\end{abstract}


Kata kunci: minyak buah merah (P. conoideus Lamk.), degumming, mikroenkapsulat, fisikokimia

\section{PENDAHULUAN}

Minyak buah merah (Pandanus conoideus Lamk.) merupakan hasil ekstrak buah merah, yang merupakan salah satu jenis buah asli daerah Papua. Minyak buah merah mengandung berbagai komponen aktif yang meliputi $\alpha$ karoten, $\beta$-karoten, $\beta$-kriptosantin, dan $\alpha$-tokoferol, serta asam lemak tidak jenuh, terutama asam oleat, linoleat, linolenat dan palmitoleat (Sarungallo dkk., 2015a; Sarungallo dkk., 2015b), yang bermanfaat bagi kesehatan tubuh. Oleh karena itu minyak buah merah sangat berpotensi untuk diolah menjadi pangan fungsional. Walaupun demikian minyak buah merah tersebut merupakan esktrak kasar yang masih mengandung fosfolipid (fosfor) dan asam lemak bebas (ALB).

Kandungan fosfolipid dalam minyak kasar merupakan masalah utama selama proses pengolahan minyak buah merah menjadi berbagai produk olahan lain seperti emulsi dan mikrokapsul, yang dapat dihilangkan melalui proses degumming. Menurut Sengar dkk., (2014) tujuan utama degumming adalah untuk mencegah adanya endapan dalam minyak kasar selama penyimpanan atau pengangkutan, mencegah pengasaman gum-gum, sebagai tahap penyaringan minyak secara fisik, mengurangi kehilangan minyak selama netralisasi, dan menghasilkan lesitin secara komersial. Dengan demikian, minyak buah merah tersebut akan mengalami perubahankimia seperti hidrolisis dan oksidasi selama penyimpanannya dan komponen aktifnya juga mengalami kerusakan. Dijelaskan pula bahwa kerusakan oksidatif pada minyak buah merah hasil pemurnian antara lain menyebabkan terbentuknya flavour yang tidak enak, stabilitas umur simpan rendah dan penurunan sifat sensori (Velasco dkk., 2003). Disamping itu dalam bentuk minyak, kemudahan menggunakannya terbatas sebagai suplemen. Salah satu alternatif dalam mengatasi masalah tersebut adalah dengan menggunakan teknologi mikroenkapsulasi.

Proses mikroenkapsulasi merupakan teknik untuk melindungi bahan inti yang semula berbentuk cair menjadi bentuk bubuk, dimana partikel mikro (droplet) dikelilingi oleh bahan penyalut dan bertindak sebagai penghalang fisik antara inti dan bahan lain yang ada dalam produk (Fang dan Bhandari, 2010). Dilaporkan bahwa minyak buah merah yang tidak dimikroenkapsulasi mempunyai daya tahan yang lebih rendah dibanding minyak buah merah yang dimikroenkapsulasi pada suhu kamar maupun suhu tinggi yaitu $60^{\circ} \mathrm{C}$ dan $70^{\circ} \mathrm{C}$ (Yanuwar dkk., 2007). Mikroenkapsulat minyak buah merah memiliki pemanfaatan lebih luas, baik sebagai ingridient (bahan tambahan makanan) yang kaya karotenoid dan tokoferol sebagai fortifikasi produk pangan, maupun sebagai pewarna alami kuning-oranye seperti pada produk permen, es krim, produk daging, dan minuman ringan (Pegg dan Shahidi, 2007). Penelitian ini bertujuan untuk menentukan sifat fisikokimia minyak buah merah hasil degumming dan karakteristik mikroenkapsulat minyak buah merah degumming.

\section{METODOLOGI}

\section{Alat dan Bahan}

Bahan utama yang digunakan pada penelitian ini adalah minyak buah merah produksi "'UKM HESTA'. Bahan-bahan yang digunakan untuk degumming minyak buah yaitu asam sitrat dan aquades. Sedangkan bahan-bahan dalam pembuatan mikrokapsul minyak buah merah hasil degumming adalah air, maltodekstrin, gum arab, gelatin, tween 80 dan carboxymethyl celluloce (CMC). Bahanbahan kimia untuk analisis kualitas minyak buah merah degumming dan mikroenkapsulat minyak buah merah adalah bipiridin (Merck), $\mathrm{FeCl}_{3} 6 \mathrm{H}_{2} \mathrm{O} \quad$ (Merck), indikator phenolphthalein (Merck), $\mathrm{K}_{2} \mathrm{Cr}_{2} \mathrm{O}_{7}$ (Merck), indikator pati, $\mathrm{KOH}$ (Merck), aquades, alkohol 95\% (Merck), heksan, BHT (butylated hidroxytoluena), $\mathrm{Na}_{2} \mathrm{SO}_{3}$ (Merck), $\mathrm{HCl}$ pekat (Merck), KI (Merck), kloroform (JT Bekker) dan aquades.

Peralatan yang digunakan antara lain peralatan gelas, timbangan analitik (WAS 220/C/2 Radwag, Polandia), hot plate, water bath, pendingin, homogenizer (WiseMix HG15A, Daihan Sci, Korea,), sentrifuse (electric, 220V, RRT. Capacity 6X15 ml Spedd 0-400 RPM), buret, labu erlenmeyer, cawan aluminium, wadah plastik, oven, desikator, vortex, cawan petri, oven, botol reagen, tabung reaksi, rak tabung reaksi, sudip, labu ukur, 
Spray Dryer B-290 (Buchi-Laboratoriums Technic, Switzerland), spektrofotometer (Shimadzu UV-2450, Kyoto, Jepang), viskometer (Viscotester VT-04F, Jepang), pipet kapiler dan termometer.

\section{Degumming Minyak Buah Merah}

Pemurnian minyak buah merah kasar (MBMK) melalui proses degumming (Sarungallo dkk., 2018). Proses degumming minyak buah merah diawali dengan pemanasan minyak kasar dalam penangas suhu $60^{\circ} \mathrm{C}$, penambahan asam sitrat $2 \%$ dan diaduk selama 5 menit. Selanjutnya penambahan air $(\mathrm{pH}$ netral) dengan perbandingan 1:2 dan diaduk merata, dilanjutkan dengan pemisahan minyak, gum dan air menggunakan sentrifugasi. Minyak hasil degumming dipisahkan dan dinetralkan kembali menggunakan air sampai air bilasanya netral ( $\mathrm{pH} 7$ ) sehingga dihasilkan minyak buah merah degumming (MBMD). Minyak hasil degumming disimpan di dalam botol kaca berwarna gelap dan disimpan dalam refrigerator sampai digunakan dalam proses mikroenkapsulat.

\section{Pembuatan Mikroenkapsulat}

Pembuatan mikroenkapsulat dilakukan dua tahap yaitu pembuatan emulsi dan proses pengeringan emulsi dengan pengering semprot (spray dryer). Formulasi pembuatan emulsi mengacu pada laporan Sarungallo dkk., (2019) dengan stabilitas terbaik dipilih untuk dibuat produk mikroenkapsulat yaitu MBMD $11 \%$, maltodextrin $18 \%$, gum arab $1,8 \%$, gelatin $0,9 \%$, CMC 0,4\%, tween $800,9 \%$ dan air $67 \%$.

Tahap awal yang dilakukan dalam pembuatan mikroenkapsulat adalah pencampuran MBMD dengan Tween 80 kemudian di mixing selama 3 menit (Bahan A). Setelah itu pencampuran air dan bahan pengemulsi maltodekstrin, gum arab, gelatin, dan CMC (Bahan B). Pencampuran bahan A dan bahan $B$ selama 15 menit dengan kecepatan 8000 rpm sampai terbentuk emulsi. Selanjutnya emulsi yang dihasilkan dikeringkan menggunakan spray drying ( $\mathrm{T}$ inlet $=170-180{ }^{\circ} \mathrm{C}, \mathrm{T}$ outlet $=80{ }^{\circ} \mathrm{C}$ laju alir bahan $8,3 \quad \mathrm{~mL} / \mathrm{menit}$ ). Selanjutnya mikroenkapsulat dikemas dan disimpan sampai tahap analisis selanjutnya.

\section{Analisis Fisikokimia Minyak \\ Analisis fisikokimia MBMK dan MBMD meliputi kadar air dengan metode}

oven (AOCS, 2003), analisis asam lemak bebas menggunakan metode titrasi (AOAC, 2012), analisis karotenoid dengan metode spektrofotometri (Knockaert dkk., 2012), analisis bilangan peroksida, metode titrasi (AOAC, 2012), analisis bilangan iod (AOAC, 2012), dan titik cair (AOAC, 2012).

\section{Analisis Mutu Mikroenkapsulat Minyak Buah Merah}

Mutu mikroenkapsulat minyak buah merah yang dianalisis meliputi kadar air dengan metode oven (AOCS, 2003), kadar lemak dengan metode sokhlet (AOCS, 2003), total karotenoid (Knockaert dkk., 2012), retensi karotenoid (Dwiyanti dkk., 2014) dan kelarutan mikroenkapsulat dalam air menggunakan metode gravimetri (Fardiaz dkk., 1992). Sedangkan pengukuran total karotenoid menggunakan metode Knockaert dkk. (2012) dan retensi karotenoid (Dwiyanti dkk., 2014) dilakukan dengan cara mengukur kadar karotenoid yang terdapat dalam bahan baku (awal) dan karotenoid dalam produk (akhir). Pengukuran retensi karotenoid dihitung dengan Persamaan berikut:

$$
\mathrm{RK}=\frac{\mathrm{A}}{\mathrm{B}} \times 100 \%
$$

Keterangan:

RK: Retensi Karotenoid (\%)

A : Jumlah karotenoid akhir

B : Jumlah karotenoid awal

\section{HASIL DAN PEMBAHASAN}

\section{Karakteristik Fisik Dan Kimia Minyak Buah Merah}

Proses degumming dengan tujuan untuk memisahkan kotoran dari gum dan getah atau lendir yang terdapat dalam minyak (Ketaren, 2005). Proses Hasil pengujian karakteristik sifat fisik dan kimia minyak buah merah kasar (MBMK) dan (MBMD) disajikan pada Tabel 1.

Titik cair dari asam lemak dipengaruhi oleh panjang rantai dan ikatan rangkap dari asam lemak. Semakin panjang rantai dan semakin rendahnya ikatan rangkap asam lemak maka semakin tinggi titik cair (Wan, 2000).

Hasil pengujian pada Tabel 1, menunjukkan bahwa proses degumming dapat menurunkan titik cair minyak buah merah. Hal ini dimungkinkan karena penggunaan asam sitrat pada proses degumming mampu 
menghilangkan beberapa kandungan minor minyak khususnya komponen gum yang terdapat dalam bentuk kompleks ester (fosfatida), protein, residu, karbohidrat, air dan resin, serta tingginya ikatan rangkap dalam minyak buah merah. Hilangnya komponen pengotor tersebut dapat menyebabkan minyak hasil degumming lebih cepat mencair karena berkurangnya rantai karbon panjang yang dikontribusi oleh makromolekul seperti protein dan karbohidrat. Hasil ini juga sejalan dengan laporan Sarungallo dkk., (2009) bahwa proses degumming dapat menurunkan titik cair MBMK dari 22,3 menjadi $20,3^{\circ} \mathrm{C}$. Selain itu, penurunan titik cair MBMD juga diakibatkan oleh meningkatnya jumlah ikatan rangkap yang ditandai dengan meningkatnya bilangan Iod dari 53,03 g $\mathrm{I}_{2} / 100 \mathrm{~g}$ menjadi $66,53 \mathrm{~g}$ $\mathrm{I}_{2} / 100 \mathrm{~g}$ (Tabel 1).

Tabel 1. Karakteristik fisik dan kimia minyak buah merah degumming

\begin{tabular}{lcc}
\hline \multicolumn{1}{c}{ Parameter } & Minyak kasar & Minyak degumming \\
\hline Titik Cair $\left({ }^{\circ} \mathrm{C}\right)$ & $24,0 \pm 0,57$ & $21,5 \pm 0,71$ \\
Viskositas $(\mathrm{dPa} . \mathrm{s})$ & $233 \pm 28,87$ & $167 \pm 28,87$ \\
Kadar air $(\%)$ & $0,92 \pm 0,11$ & $0,78 \pm 0,04$ \\
Asam lemak bebas $(\%)$ & $0,66 \pm 0,07$ & $0,55 \pm 0,07$ \\
Bil. Peroksida $\left(\mathrm{mg} \mathrm{O}_{2} / \mathrm{g}\right.$ bahan $)$ & $0,7 \pm 0,12$ & $0,56 \pm 0,12$ \\
Bilangan Iod $\left(\mathrm{g} \mathrm{I}_{2} / 100 \mathrm{~g}\right)$ & $53,03 \pm 0,88$ & $66,53 \pm 0,43$ \\
Total Karotenoid $(\mathrm{ppm})$ & $6299 \pm 94$ & $5941 \pm 101$ \\
Total Tokoferol $(\mathrm{ppm})$ & $1920 \pm 122$ & $1586 \pm 96$ \\
\hline
\end{tabular}

Viskositas menyatakan ukuran tingkat kekentalan atau kemampuan suatu fluida untuk mengalir. Semakin tinggi nilai viskositas mengindikasikan bahwa maka makin kental minyak tersebut (Gardjito dan Supriyanto, 1987). Data pada Tabel 1, menunjukkan bahwa proses degumming dapat menurunkan viskositas MBMK dari 233 d.Pas menjadi 167 d.Pas (MBMD). Penurunan viskositas ini diduga akibat berkurangnya gum dan lendir pada proses degumming, sehingga kadar minyak buah merah dengan tingkat ketidakjenuhannya yang tinggi meningkat. Sarungallo dkk., (2009) juga melaporkan bahwa proses degumming dapat menurunkan viskositas MBMK, yang diduga akibat berkurangnya asam lemak rantai panjang dan asam lemak jenuh yang ditandai dengan meningkatnya bilangan iod yang menandakan terjadi peningkatan asam lemak tidak jenuh.

Tingginya kadar air di dalam minyak akan memicu terjadinya reaksi hidrolisis (Ketaren, 2005), untuk itu minyak yang bermutu memiliki kandungan air yang rendah. Standar minyak buah merah hingga saat ini belum ditetapkan, namun jika mengacu pada SNI CPO maka kadar air maksimalnya sebesar $0,5 \%$ (SNI). Hasil analisis pada Tabel 1, menunjukkan bahwa kadar air untuk MKBM sebesar 0,92\% dan MDBM sebesar 0,78\%, yang menunjukkan bahwa kedua jenis minyak tersebut memiliki kadar air yang lebih tinggi dibandingkan dengan SNI. Tingginya kadar air MBMK karena proses ekstraksi minyak buah merah pada "UKM HESTA" menggunakan metode ekstraksi basah dimana diduga proses pemisahan air tidak berlangsung baik sehingga jumlah air yang terikut dalam minyak masih cukup tinggi. Sedangkan tingginya kadar air pada MBMD diduga pada proses degumming menggunakan air dalam proses pencucian, dimana sebagian air terikut di dalam minyak, akibatnya kadar air menjadi tinggi. Dari data tersebut menunjukkan bahwa proses degumming tidak dapat menurunkan kadar air minyak buah merah. Hasil ini sejalan dengan laporan Sarungallo dkk., (2020) bahwa proses degumming tidak berpengaruh nyata terhadap kadar air minyak buah merah yang dimurnikan.

Asam lemak bebas (ALB) merupakan parameter penting untuk menentukan standar mutu minyak. ALB yang terbentuk merupakan hasil dari reaksi hidrolisis yang dipengaruhi oleh adanya peningkatan suhu, air dan katalis (Enzim). Semakin lama reaksi berlangsung, maka semakin banyak ALB yang terbentuk (Ketaren, 2005). Berdasarkan data pada Tabel 1, menunjukkan bahwa Kadar ALB MBMK $0,66 \%$ lebih tinggi dibandingkan minyak buah merah degumming $0,55 \%$, namun belum dapat menurunkan kadar asam lemak secara maksimal. Hal ini disebabkan karena pada proses degumming tidak dapat menurunkan 
kadar ALB pada minyak buah merah. Mayalibit dkk., (2019) dan Sarungallo dkk., (2020) juga melaporkan bahwa proses degumming tidak mempengaruhi penurunan kadar ALB minyak buah merah kasar. Lebih lanjut Ketaren (2005) menjelaskan bahwa kadar asam lemak dalam suatu minyak dapat diturunkan dengan cara netralisasi, dimana asam lemak bebas akan direaksikan dengan basa atau pereaksi lainnya sehingga membentuk sabun. Santoso dkk., (2018) melaporkan bahwa pemurnian minyak buah merah degumming melalui tahap netralisasi dengan menggunakan larutan $\mathrm{NaOH} 1,25 \mathrm{~N}$, dapat menurunkan kadar ALB minyak buah merah dari $1,15 \%$ menjadi 0,31\%. Kadar ALB pada MBMK dan MBMD (Tabel 1) masih di atas batas maksimum kadar ALB pada minyak sawit menurut Standar Nasional Indonesia (2006) yaitu 0,3\%. Meningkatnya kadar ALB dapat disebabkan karena terjadi reaksi hidrolisis selama proses ekstraksi berlangsung yang dipengaruhi oleh suhu, udara, waktu pemanasan yang lama dan wadah yang digunakan dalam mengekstrak minyak buah merah. (Murtiningrum, 2004; Santoso dkk., 2018; Sarungallo dkk., 2020).

Bilangan peroksida merupakan salah satu indikator penting untuk menentukan tingkat kerusakan minyak akibat proses oksidasi, yang terbentuk karena oksigen bereaksi dengan asam lemak tidak jenuh (Ketaren, 2005). Data pada Tabel 1, menunjukkan bahwa hasil pengukuran bilangan peroksida MBMK yaitu sebesar 0,7 mg $\mathrm{O}_{2} / \mathrm{g}$ bahan dan minyak buah merah degumming sebesar $0,56 \mathrm{mg} \mathrm{O}_{2} / \mathrm{g}$ bahan, relatif masih rendah. Sementara itu, Sarungallo dkk., (2020) dan Mayalibit dkk., (2019) melaporkan bahwa proses degumming tidak mempengaruhi bilangan peroksida minyak buah merah kasar.

Penurunan bilangan peroksida pada minyak buah merah degumming disebabkan penambahan asam sitrat, yang dapat bertindak sebagai pengkelat ion logam dan senyawa organologam, dengan cara menginaktif logamlogam yang dapat bertindak sebagai katalis oksidasi (Anderson, 2005). Namun jika dibandingkan dengan bilangan peroksida maksimum minyak sawit menurut SNI (2006) adalah $10 \mathrm{mg} \quad \mathrm{O}_{2} / 100 \mathrm{~g}$, nilai bilangan peroksida MBMD lebih rendah. Rendahnya nilai bilangan peroksida pada minyak buah merah dapat terjadi karena adanya komponen aktif seperti karotenoid dan tokoferol di dalam minyak buah merah yang cukup tinggi (Tabel 2). Karotenoid dan tokoferol berfungsi sebagai senyawa antioksidan. Djatmiko dan Widjaya (1973), menyatakan bahwa minyak cenderung untuk bereaksi dengan oksigen secara autooksidasi, tidak saja tergantung pada komposisi asam lemaknya, tetapi juga pada komponen-komponen yang terkandung di dalamnya. Adanya bahan yang bersifat antioksidan alami seperti karotenoid dan tokoferol atau beberapa logam berat tertentu seperti tembaga dan besi yang dapat juga bertindak sebagai prooksidan. Dengan demikian, rendahnya nilai bilangan peroksida pada minyak buah merah dapat dihubungkan dengan adanya kandungan sejumlah karotenoid dan tokoferol yang dapat berperan juga sebagai antioksidan, sehingga proses oksidasi lemaknya dapat dicegah.

Minyak buah merah dikenal mempunyai komponen aktif yang sangat penting yaitu karotenoid dan tokoferol (Surono dkk., 2008). Data pada Tabel 2 menunjukkan total karotenoid MBMK adalah 6299 ppm dan MBMD 5941 ppm serta tokoferol MBMK 1920 ppm dan MBMD 1586 ppm. Hal ini menunjukkan bahwa proses pemurnian dengan degumming dapat menurunkan total karotenoid dan tokoferol minyak buah merah. Nilai total karotenoid dan total tokoferol lebih rendah pada MBMD diduga akibat terjadinya degradasi pada saat proses degumming dimana minyak dicuci menggunakan air (Hasibuan dkk., 2012). Disamping itu air pencucian yang digunakan pada proses degumming memiliki suhu $50^{\circ} \mathrm{C}$, sehingga memicu degradasi karotenoid. Menurut Wilska dan Jeszka (2002), karotenoid dan tokoferol sangat sensitif terhadap oksigen, cahaya, dan suhu karena memiliki ikatan rangkap terkonyugasi sehingga mengandung banyak elektron reaktif dan mudah teroksidasi.

Bilangan iod dinyatakan sebagai jumlah gram iod yang diserap oleh $100 \mathrm{~g}$ minyak dan lemak. Asam lemak yang tidak jenuh dalam minyak dan lemak mampu menyerap sejumlah iod dan membentuk senyawa yang jenuh. Data pada Tabel 1, memperlihatkan bahwa bilangan iod minyak buah merah tanpa degumming $\left(53,03 \mathrm{~g} \mathrm{I}_{2} / 100\right.$ g) rendah dibandingkan dengan yang di degumming $\left(66,53 \quad \mathrm{~g} \quad \mathrm{I}_{2} / 100 \quad \mathrm{~g}\right)$ yang mengindikasikan meningkatnya ikatan rangkap (tidak jenuh). Hal ini dapat dimungkinkan 
karena proses degumming dapat menurunkan senyawa-senyawa yang tidak diinginkan yaitu senyawa-senyawa jenuh berupa pecahan peroksida maupun komponen-komponen gum. Sarungallo dkk., (2020) juga melaporkan bahwa bilangan iod minyak buah merah kasar sebesar 80,9 $\mathrm{g} \mathrm{I}_{2} / 100 \mathrm{~g}$ cenderung meningkat setelah di-degumming menjadi $82,4 \mathrm{~g} / 100 \mathrm{~g}$. Standar bilangan iod minyak sawit menurut SNI (2006) sebesar 50-55 (g I/ 100 g minyak), lebih rendah dibandingkan bilangan iod MBMD yang dihasilkan dalam penelitian (Tabel 1).

\section{Karakteristik Mutu Mikroenkapsulat MBMD}

Mikroenkapsulasi adalah suatu teknologi pembungkusan padatan, cairan atau gas, dengan suatu dinding atau lapisan tipis sehingga dapat menghambat volatilisasi dan melindungi dari reaksi degradasi, mencegah kehilangan flavor dan aroma, mengubah bentuk cair ke padatan sehingga mudah diaplikasikan dan dapat memperpanjang umur simpan (Pegg dan Shahidi, 2007). Karakteristik mikroenkapsulat MBMD, diantaranya kadar air, bilangan peroksida, kadar lemak, karotenoid, retensi karotenoid dan kelarutan disajikan pada Tabel 2 .

Tabel 2. Karakteristik Mikroenkapsulat mutu Minyak Buah Merah

\begin{tabular}{lc}
\hline \multicolumn{1}{c}{ Parameter } & Mikroenkapsulat MBMD \\
\hline Kadar air (\%) & $0,55 \pm 0,10$ \\
Bil. Peroksida (mg O $/$ /g bahan) & $0,49 \pm 0,12$ \\
Kadar Lemak (\%) & $38,31 \pm 1,30$ \\
Total Karotenoid (ppm) & $635 \pm 19,78$ \\
Retensi Karotenoid (\%) & $97,17 \pm 0,01$ \\
Kelarutan $(\%)$ & $93,45 \pm 0,69$ \\
\hline
\end{tabular}

Kadar air menunjukkan persentase air dalam mikroenkapsulat. Air merupakan salah satu faktor yang dapat memicu kerusakan, semakin tinggi kadar air dari mikroenkapsulat maka peluang mengalami kerusakan akan semakin tinggi. Berdasarkan data yang diperoleh (Tabel 2), kadar air mikroenkapsulat sebesar $0,55 \%$. Nilai ini masih masuk dalam standar jika dibandingkan dengan produk susu bubuk dalam SNI (1999) yaitu maksimal 5\%. (Tabel 2). Nilai kadar air ini relatif lebih rendah dibandingkan dengan laporan Sarungallo dkk. (2019) kadar air mikroenkapsulat minyak buah merah yang dihasilkan berkisar $1,021 \%$ dan relatif sama dengan laporan Fasikhatun (2010) pada produk mikroenkapsulat minyak sawit berkisar 0,62$2,92(\%, \quad b b)$. Christidianti (2015) juga melaporkan bahwa kadar air mikroenkapsulat minyak sawit yang dihasilkan sebesar 1,04\%.

Bilangan peroksida adalah nilai terpenting untuk menentukan derajat kerusakan pada minyak atau lemak. Hasil analisis menunjukkan bilangan peroksida mikroenkapsulat MBMD sebesar 0,49 $\mathrm{mg} \mathrm{O}_{2} / \mathrm{g}$ bahan (Tabel 2) lebih rendah jika dibandingkan dengan bilangan peroksida MBMD sebesar 0,56 (Tabel 2). Hal ini menunjukkan bahwa proses mikroenkapsulasi dapat memberikan perlindungan yang efektif terhadap kerusakan oksidatif minyak atau lemak serta membuktikan bahwa dengan proses mikroenkapsulasi dapat mengurangi tingkat kerusakan pada minyak dengan cara menekan laju oksidasi sehingga mikroenkapsulat tetap stabil (Novia, 2009). Mikroenkapsulat MBMD memiliki bilangan peroksida yang lebih rendah yaitu $0,49 \mathrm{mg}$ $\mathrm{O}_{2} / \mathrm{g}$ bahan dibandingkan dengan mikroenkapsulat minyak sawit yang diperoleh Qhistina (2015) sebesar 7,17 $\mathrm{mg} \mathrm{O}_{2} / \mathrm{g}$ bahan.

Lemak adalah trigliserida yang termasuk golongan lipida. Secara umum lemak diartikan sebagai trigliserida yang dalam suhu ruang berada dalam keadaan padat (Sudarmadji dkk., 1989). Berdasarkan analisis yang dilakukan, kadar lemak mikroenkapsulat MBMD adalah $38,31 \%$. Nilai Kadar lemak mikroenkapsulat MBMD diperoleh dari $11 \%$ minyak buah merah degumming yang ditambahkan dalam formulasi (Tabel 3). Kadar lemak mikroenkapsulat MBMD cukup tinggi, hal ini disebabkan kadar lemak dari minyak buah merah sangat tinggi.

Total karoten merupakan parameter yang penting untuk dianalisis, karena menunjukkan kemampuan penyalut dalam mempertahankan karoten setelah proses 
pengeringan. Ada-nya berbagai perlakuan selama proses dapat menyebabkan turunnya kadar karoten dalam mikroenkapsulat (Simanjuntak, 2007). Kadar total karotenoid pada produk mikroenkapsulat MBMD adalah 635 ppm (Tabel 2) berasal dari 11\% MBMD yang ditambahkan dalam formulasi. Total karotenoid mikroenkapsulat MBMD lebih tinggi jika dibandingkan dengan total karotenid pada mikroenkapsulat yang dianalisis oleh Chrisdianti (2015) yaitu 345 ppm dengan formulasi minyak sawit $12,40 \%$.

Retensi karotenoid merupakan nilai perbandingan antara kadar total karotenoid yang terdapat di dalam minyak setelah menjadi mikroenkapsulat dengan kandungan total karoten awal minyak sebelum mengalami proses mikroenkapsulasi dikali dengan seratus persen. Besar kecilnya nilai retensi karotenoid sangat ditentukan oleh kondisi proses pengeringan, kandungan karoten awal minyak sawit, proporsi bahan-bahan mikroenkapsulat yang mampu melindungi karoten dari kerusakan selama pengolahan. Retensi karotenoid mikroenkapsulat MBMD adalah 97,17\% (Tabel 2), retensi karotenoid mikroenkapsulat MBMD lebih tinggi jika dibandingkan dengan nilai retensi mikroenkapsulat minyak sawit yang diperoleh Christdianti (2015) adalah sebesar 79,62\%, hal ini menunjukkan bahwa bahan penyalut yang digunakan sudah baik untuk melindungi karotenoid selama proses mikroenkapsulat berlangsung. Ton dkk., (2016) menjelaskan pula bahwa penggabungan antara karbohidrat dengan protein sebagai bahan penyalut dapat meningkatkan stabilitas emulsi dan perlindungan yang lebih baik terhadap bahan inti.

Kelarutan sangat dipengaruhi oleh kadar air dari suatu bahan, penurunan kelarutan seiring dengan peningkatan kadar air. Pada penelitian Novia (2009), penurunan kelarutan seiring dengan peningkatan kadar air mikroenkapsulat minyak sawit. Mikroenkapsulat minyak buah merah degumming memiliki tingkat kelarutan yang tinggi, nilai kelarutan pada mikroenkapsulat MBMD sebesar 93,45\%, nilai kelarutan ini lebih tinggi dibandingkan nilai kelarutan yang dilaporkan Sarungallo dkk., (2019) yaitu kelarutan mikroenkapsulat minyak buah merah yang dihasilkan berkisar $50-80 \%$, yang dipengaruhi jenis dan konsentrasi bahan penyalut yang digunakan. Simanjuntak (2007) melaporkan bahwa rata- rata nilai kelarutan mikroenkapsulat minyak sawit merah adalah $78,14 \%$. Tingginya kelarutan mikroenkapsulat MBMD ini disebabkan adanya maltodekstrin. Maltodekstrin dapat larut dengan sempurna dalam air dingin, dengan viskositas yang rendah pada padatan tinggi sehingga memiliki sifat kelarutan yang tinggi (Balasubramani dkk., 2014). Selain maltodekstrin, gum arab juga memiliki kelarutan yang tinggi di dalam air, sehingga kombinasi keduanya menghasilkan mikrokapsul dengan nilai kelarutan dalam air tinggi (Kanakdande dkk., 2007).

\section{KESIMPULAN}

Hasil penelitian menunjukkan bahwa teknik mikroenkapsulat minyak buah merah degumming (MBMD) dapat meningkatkan mutu minyak buah merah degumming yang diindikasikan dengan menurunnya persentase kadar asam ALB, kadar air dan bilangan peroksida. Karakteristik minyak buah merah degumming (MBMD) yaitu memiliki nilai kadar air $0,78 \%$, ALB $0,55 \%$, bilangan peroksida $0,56 \mathrm{mg} \mathrm{O}_{2} / \mathrm{gr}$ bahan, total karotenoid $5941 \mathrm{ppm}$, tokoferol $1586 \mathrm{ppm}$, bilangan iod $66,53 \mathrm{~g} \mathrm{I}_{2} / 100 \mathrm{~g}$, titik cair $21,5^{\circ} \mathrm{C}$ dan viskositas 167 dPa.s. Karakteristik mikroenkapsulat MBMD yaitu memiliki kadar air $0,55 \%$, bilangan peroksida $0,49 \mathrm{mg} \mathrm{O}_{2} / \mathrm{gr}$ bahan, kadar lemak $38,31 \%$, total karotenoid 635 ppm, retensi karotenoid 97,17\% dan kelarutan 93,45\%. Mikroenkapsulat MBMD telah memenuhi standar mutu produk kering (susu bubuk) menurut SNI (1999) untuk kadar air dan bilangan peroksida.

\section{UCAPAN TERIMA KASIH}

Peneliti mengucapkan terima kasih kepada Kementerian Riset dan Teknologi Direktorat Jenderal Pendidikan Tinggi, atas dana yang diberikan melalui Hibah Penelitian Strategis Nasional tahun 2017, dengan nomor kontrak 059/SP2H/DRPM/II/2016.

\section{DAFTAR PUSTAKA}

Anderson, D., (2005), a Primer on Oils Processing Technology, dalam: F. Shahidi (Ed.). Oil and Fat Products: Processing Technologies. Bailey's Industrial Oil and Fat Products. Sixth 
Edition Volume 5 Edible John Wiley \& Sons, Inc., Publication. New Jersey

AOAC (Association of Official Analytical Chemistry), (2012), Official Metods of Analysis of the AOAC. $15^{\text {th }}$ Ed. AOAC Inc., Arlington.

AOCS (American Oil Chemists' Society), (2003), Official Methods and Recommended Practices of the AOCS. $5^{\text {th }}$ Ed. AOCS. Champaign, Illinois.

Balasubramani, P., Palaniswamy, P.T., Visvanathan, R., Thirupathi, V., Subbayaran, A., and Maran, J.P., (2014), Mikroencapsulation of garlic oleoresin using maltodextrin as wall material by spray drying technology. International journal of biological macromolecules 72(1), pp. 210-217.

Christdianti, R., (2015), Proses Mikroenkapsulasi Minyak Sawit Dan Analisis Teknoekonomi Pada Skala Industri. [Skripsi]. Fateta, Institut Pertanian Bogor, Bogor.

Djatmiko, B., dan Widjaja, A.P., (1973). Minyak dan Lemak. Departemen Teknologi Hasil Pertanian. Institut Pertanian Bogor. Bogor.

Dwiyanti, H., Riyadi, H., Rimbawan, Darmayanthi, E., dan Sulaeman, A., (2014), Penambahan CPO dan RPO sebagai sumber provitamin A terhadap retensi karoten, sifat fisik, dan penerimaan. Teknologi Industri Pertanian, 24(1), pp. 28- 33.

Fang, Z., and Bhandari, B., (2010), Encapsulation of polyphenols - a review. Trends in Food Science and Technology. 21, pp. 510- 523.

Fasikhatun, T., (2010), Pengaruh konsentrasi maltodekstrin dan gum arab tehadap karakteristik mikroenkapsulat minyak sawit merah dengan metode spray drier. [Skripsi]. Institut Pertanian Bogor, Bogor.

Gardjito, M., dan Supriyanto, (1987), Teknologi Pengolahan Minyak. Pusat Antar Universitas Pangan dan Gizi. Universitas Gadjah Mada. Yogyakarta.

Hasibuan, H.A., Siahaan, D., dan Sunarya, (2012), Kajian Karakteristik Minyak Inti Sawit Indonesia dan Produk Fraksinasinya Terkait dengan Amandemen Standar Codex. Jurnal Standardisasi, 14, pp. 98-104.
Kanakdande, D., Bhosale, R., dan Singhal, R.S., (2007), Stability cumin oleoresin microencapsulated in different combination of gum Arabic, maltodextrin, and modified starch. Carbohydrate polymer, 67, pp. 536-541.

Ketaren, S., (2005), Pengantar Teknologi Minyak dan Lemak Pangan. UI-Press. Jakarta.

Knockaert, G., Lemmens, L., Van Buggenhout, S., Hendrickx, M., and Van Loey, A., (2012), Changes in $\beta$ carotene bioaccessibility and concentration during processing of carrot puree. Food Chemistry, 133(1), pp. 60-67. https://doi.org/10.1016/j.foodchem.2011 .12 .066 .

Mayalibit, A. P., Sarungallo, Z. L., dan Paiki, S. N. P., (2019). Pengaruh Proses Degumming Menggunakan Asam Sitrat Terhadap Kualitas Minyak Buah Merah (Pandanus conoideus Lamk). Agritechnology, 2(1), pp. 23-31.

Murtiningrum, (2004), Ekstraksi Minyak Dengan Metode Wet Rendering dari Buah Pandan (Pandanus conoideus L.) dan Pemurnian dengan Filtrasi Membran. (Tesis). Pasca Sarjana. Institut Pertanian Bogor, Bogor.

Novia, S., (2009), Stabilitas mikroenkapsulat minyak sawit merah hasil pengeringan lapis tipis selama penyimpanan. (Skripsi). Fakultas Teknologi Pertanian, Institut Pertanian Bogor, Bogor.

Pegg, R.B., dan Shahidi, F., (2007), Encapsulation, stabilization, and controlled release of food ingredients and bioactives. Handbook of Food Preservation. CRC Press, New York, pp. 509-570.

Qhistina, F.G., (2015), Studi Kinetika Perubahan Mutu Mikroenkapsulat Minyak Sawit Merah selama Penyimpanan. (Skripsi). Fakultas Teknologi Pertanian, Institut Pertanian Bogor, Bogor.

Santoso, B., Zita L. Sarungallo, Z.L., Situngkir, R.U., Roreng, M.K., Lisangan, M.M., dan Murni, V., (2018), Mutu kimia minyak dan komponen aktif minyak buah Merah (Pandanus conoideus L.) yang dinetralisasi menggunakan larutan alkali. Agritechnology, 1(2), pp. 66-75. 
Sarungallo, Z.L., Murtiningrum, dan Paiki, S. N. P., (2009), Sifat Fisikokimia Minyak Kasar dan Hasil Degumming dari Buah Merah (Pandanus conoideus L.) yang diekstrak secara Tradisional Merdey. Jurnal Agrotek, 1(6), pp. 9-15.

Sarungallo, Z. L., Hariyadi, P., Andarwulan, N., Purnomo, E. H., and Wada, M., (2015a), Analysis of $\alpha$-cryptoxanthin, $\beta$ cryptoxanthin, $\alpha$-carotene, and $\beta$ carotene of Pandanus conoideus oil by high-performance liquid chromatography (HPLC). Procedia Food Science, pp. 231-243.

Sarungallo, Z.L., Hariyadi, P., Andarwulan, N. and Purnomo, E. H., (2015b), Characterization of chemical properties, lipid profile, total phenol and tocopherol content of oils extracted from nine clones of red fruit (Pandanus conoideus). Kasetsart Journal (Nature Science) 49, pp. 237-250.

Sarungallo, Z.L., Santoso, B., Lisangan, M. M., Paiki, S. N. P., Situngkir, R. U., dan Asokawati, E., (2018), Kinetika perubahan mutu minyak buah merah (Pandanus conoideus) hasil degumming selama penyimpanan. Jurnal Aplikasi Teknologi Pangan, 7(4), pp. 156-162.

Sarungallo, Z.L., Santoso, B., Murtiningrum, Roreng, M. K., dan Murni, V., (2019), Karakteristik mutu mikroenkapsulat minyak buah merah (Pandanus conoideus) dengan perbandingan konsentrasi bahan pengemulsi dan bahan pelapis. Pro Food (Jurnal Ilmu dan Teknologi Pangan), 5(2), pp. 528-539.

Sarungallo, Z. L., Santoso, B., Situngkir, R. U., Roreng, M.K., dan Lisangan, M. M., (2020), Determination of chemical properties, composition of fatty acid, carotenoids and tocopherols of degummed and neutralized red fruit (Pandanus conoideus) oil. Jurnal Teknologi (Science and Technology), 82 (6), pp. 71-78.

Sengar, G., Kaushal, P., Sharma, H. K., and Kaur, M., (2014), Degumming of rice bran oil. Reviews in Chemical
Engineering, 30 (2), pp. 183-198. DOI: 10.1515/revce2013-0030.

Simanjuntak, M., (2007), Optimasi formulasi mikroenkapsulat minyak sawit merah menggunakan maltodekstrin, gelatin, dan carboxymerhyl cellulose dengan proses TLayer drying. (Skripsi). Fakultas Teknologi Pertanian, Institut Pertanian Bogor, Bogor.

SNI (Standar Nasional Indonesia), (2006), Minyak kelapa sawit. Badan Standarisasi Nasional. Jakarta.

Sudarmadji, S., Haryono, B. dan Suhardi. (1997). Prosedur Analisis Bahan Makanan dan Pertanian. Liberty. Yogyakarta.

Surono, I., Endaryanto, T.A., and Nishigaki, T., (2008), Indonesian biodiversities, from microbes to herbal plants as potential functional foods. Journal of the Faculty of Agriculture Shinshu University, 44(1.2), pp. 23-27.

Ton, N.M.N., Tran, T.T.T., and Le, W.M., (2016), Microencapsulation of rambutan seed oil by spray drying using different protein preparations. International Food Research Journal, 23(1), pp. 123-128.

Velasco, P.J., Dobarganes, C., and MarquezRuiz, G., (2003), Variables affecting lipid oxidation in dried microencapsulated oils. Grasas y Aceites, 54 (3), pp. 304-314.

Wan, P.J., (2000), Properties of Fats and Oils. In: R.D. O'Brien, W.E.Farr, and P.J. Wan (Ed.). Introduction to Fats and Oils Technology. AOCS Press, Champaign.

Wilska-Jeszka, J., (2002), Food Colorants. Dalam: Sikorski, Z.E. (ed.), Chemical and Functional Properties of Food Components. Second Edition, CRC Press, New York.

Yanuwar, W., Widjanarko, S.B., and Wahono, T., (2007), Karakteristik dan stabilitas antioksidan mikroenkapsulat minyak buah merah (Pandanus conoideus Lamk.) dengan bahan penyalut berbasis protein. Jurnal Teknologi Pertanian, 8(2), pp. 127-135. 